\title{
EFEKTIVITAS DAN EFISIENSI PEMBELAJARAN BERBASIS BLENDED LEARNING DI MADRASAH TSANAWIYAH NEGERI MODEL PALU
}

\author{
Ramang \\ Dosen FTIK IAIN Palu
}

The learning process in the Palu State Islamic Education Madrasah has run as it should, although in terms of strategies, methods, and learning media used varies according to the conditions, both the material and the condition of the students, and the ability of the teacher itself is different from one another. Blended learning based learning at the Palu Model State Islamic Education Madrasah is considered effective and efficient because teachers are not preoccupied with making material designs, simply accessing the internet is needed including practice in the form of videos so that it will facilitate teachers, both in terms of time, effort and cost. The challenge of blended learning is that teachers are required to be more creative and able to use internet networks. While the opportunity is the Madrasah Tsanawiyah Negeri Model Palu already equipped with network facilities and infrastructure that can support blended learning.

Keywords: Learning, blended learning, effectivity

Proses pembelajaran pada Madrasah Tsanawiyah Negeri Model Palu telah berjalan sebagaimana mestinya, walaupun dari segi strategi, metode, dan media pembelajaran yang digunakan bervariasi sesuai dengan kondisi, baik materi maupun keadaan peserta didik, serta kemampuan guru itu sendiri berbeda antara satu dengan yang lainnya. Pembelajaran berbasis blended learning di Madrasah Tsanawiyah Negeri Model Palu dianggap efektif dan efisien karena guru tidak disibukkan membuat rancangan materi, cukup mengakses internet yang dibutuhkan termasuk prakteknya dalam bentuk video sehingga akan memudahkan guru, baik dari segi waktu, tenaga dan biaya. Adapun tantangan pembelajaran blended learning adalah guru dituntut lebih kreatif dan mampu menggunakan jaringan internet. Sedangkan peluangnya adalah Madrasah Tsanawiyah Negeri Model Palu sudah dilengkapi sarana dan prasarana jaringan yang dapat menunjang pembelajaran blended learning.

Kata Kunci: Pembelajaran, blended learning, efektifitas. 


\section{Pendahuluan}

Penyelenggaraan pendidikan Agama Islam pada sekolah merupakan bentuk penjabaran amanat Undang-Undang Nomor 20 Tahun 2003 tentang Sistem Pendidikan Nasional. Hal ini secara jelas dinyatakan bahwa tujuan pendidikan nasional adalah "untuk berkembangnya potensi peserta didik agar menjadi manusia yang beriman dan bertaqwa kepada Tuhan Yang Maha Esa, berakhlak mulia, sehat, berilmu, cakap, kreatif, mandiri dan menjadi warga negara yang demokratis serta bertanggung jawab"1

Upaya mewujudkan peserta didik sebagaimana dalam tujuan pendidikan nasional tersebut harus melalui suatu proses, salah satunya adalah proses pembelajaran, maka sebagai tindak lanjut dari undang-undang tersebut, lahirlah peraturan Menteri Pendidikan dan Kebudayaan Republik Indonesia Nomor 103 tahun 2014 tentang Pembelajaran pada Pendidikan Dasar dan Pendidikan Menengah sebagai berikut :

1. Pembelajaran adalah proses interaksi antar peserta didik dan antara peserta didik dengan pendidik dan sumber belajar pada suatu lingkungan belajar;

2. Pembelajaran menggunakan pendekatan, strategi, model, dan metode yang mengacu pada karakteristik.

3. Pendekatan pembelajaran merupakan cara pandang pendidik yang digunakan untuk menciptakan lingkungan pembelajaran yang memungkinkan terjadinya proses pembelajaran dan tercapainya kompetensi yang ditentukan

4. Strategi pembelajaran merupakan langkah sistematik yang digunakan pendidik untuk menciptakan lingkungan pembelajaran yang memungkinkan terjadinya proses pembelajaran dan tercapainya kompetensi yang ditentukan;

5. Model pembelajaran merupakan kerangka konseptual dan operasional pembelajaran yang memiliki nama, ciri, urutan logis, pengaturan dan budaya;

${ }^{1}$ Undang-Undang Nomor 20 Tahun 2003 tentang Sistem Pendidikan Nasional, .3 
6. Metode pembelajaran merupakan cara atau teknik yang digunakan oleh pendidik untuk menangani suatu kegiatan pembelajaran yang mencakup antara lain, ceramah, Tanya jawab dan diskusi" "2

Berdasarkan Peraturan Menteri Pendidikan dan Kebudayaan tersebut, nampaklah bahwa untuk mencapai tujuan pendidikan harus melalui proses pembelajaran, karena dalam peraturan Menteri Pendidikan dan Kebudayaan dinyatakan bahwa proses pembelajaran menggunakan pendekatan, strategi, model dan metode yang mengacu pada karakteristik materi dan peserta didik. Oleh karena itu seorang guru dituntutmemiliki kompetensi untuk menerapkan proses pembelajaran tersebut.Pembelajaran merupakan upaya untuk mengarahkan anak didik ke dalam proses pembelajaran sehingga mareka dapat memperoleh tujuan belajar sesuai dengan apa yang diharapkan. Pembelajaran hendaknya memperhatikan kondisi individu peserta didik, karena merekalah yang akan belajar.

Proses pembelajaran dapat terlaksana dengan baik apabila guru-gurunya profesional dan kompeten sebagaimana dalam pasal 42 ayat 1 yang berbunyi: "Pendidik harus memiliki kualifikasi minimum dan sertifikasi sesuai dengan jenjang kewenangan mengajar, sehat jasmani dan rohani, serta memiliki kemampuan untuk mewujudkan tujuan pendidikan Nasional ${ }^{3}$

Guru merupakan tenaga pendidik yang mempunyai tugas pokok melaksanakan kegiatan belajar mengajar. Tugas guru tidaklah ringan karena harus meningkatkan kualitas sumber daya manusia sesuai standar kompetensi tertentu serta norma dan nilai-nilai yang berlaku yaitu : guru bertugas menstransfer pengetahuan dan keterampilan sesuai dengan kurikulum yang berlaku, guru berfungsi untuk meningkatkan pengetahuan dan keterampilan peserta didik sehingga kelak akan menjadi orang yang memiliki pengetahuan yang luas serta ketrampilan yang tinggi, guru harus pandai memberikan motivasi kepada peserta didiknya agar peserta didik bersedia dengan senang hati

\footnotetext{
${ }^{2}$ Peraturan Menteri Pendidikan dan Kebudayaan Nomor 103 Tahun 2014, .3

${ }^{3}$ Undang-Undang Nomor 14 Tahun 2005 tentang Guru dan Dosen,. 
mengembangkan dan memperluas pengetahuan dan keterampilan yang diberikan dalam kelas dengan memanfaatkan sumber-sumber informasi yang ada, baik cetak maupun elektronik atau istilah yang sangat populer sekarang ini adalah pembelajaran berbasis blended learning.

Pembelajaran berbasis blended learning (pembelajaran dengan pendekatan campuran) sekarang menjadi popular dan banyak digunakan di Amerika, Inggris dan Australia, dan pada perkembangannya banyak digunakan di kalangan akademik, termasuk di Indonesia pada umumnya, dan kota Palu pada khususnya. Pembelajaran blended learning pada hakekatnya mengacu pada kombinasi antara pembelajaran online dan pembelajaran tatap muka (face to face), namun demikian kombinasi dan teknologi, lokasi atau pendekatan pedagogik lain, juga semakin sering diidentifikasikan sebagai blended learning.

Blended learning merupakan proses pembelajaran yang memanfaatkan berbagai macam pendekatan. Pendekatan yang dilakukan dapat memanfaatkan berbagai macam media dan teknologi. Pembelajaran berlangsung secara konvensional (tatap muka), mandiri, dan mandiri via online. Bahan belajar mandiri secara offline disiapkan dalam bentuk digital, seperti dalam bentuk CD, DVD dan lain-lain.

Zaman sekarang ini perkembangan media, khususnya media elektronik sangat cepat, perkembangan tersebut tentunya akan menjadi potensi yang sangat besar untuk meningkatkan kualitas pendidikan. Melalui media teknologi informasi yang dapat menyimpan informasi tentang segala hal yang tak terbatas, untuk kepentingan pengembangan pendidikan yang tidak lagi dibatasi oleh ruang dan waktu. Hal ini di samping menjadi peluang, tetapi juga sebagai tantangan besar bagi guru, karena dituntut untuk mengerti, memahami, mengoperasikan dan mengeksplor media computer dengan baik sehingga dapat diaplikasikan dalam pembelajaran, di samping itu, guru harus berpikir lebih kreatif, inovatif dan berwawasan luas sehingga dapat meningkatkan kualitas pembelajaran. 


\section{Pembelajaran Model Blended Learning}

Kata "pembelajaran merupakan akumulasi dari konsep mengajar (teaching) dan konsep belajar (learning) ${ }^{4}$.pembelajaran merupakan suatu proses interaksi antara komponen-komponen dalam sistem pembelajaran. Proses pembelajaran yang telah direncanakan dengan baik akan mencapai tujuan yang telah ditetapkan. Proses pembelajaran menerapkan kemampuan dengan menggunakan sarana serta mengikuti mekanisme yang telah diatur dalam RPP atau SAP, yang meliputi kegiatan membuka sampai menutup pelajaran.

Pembelajaran merupakan proses interaksi peserta didik dengan pendidik dan sumber belajar pada suatu lingkungan belajar. Pembelajaran dapat berupa bantuan yang diberikan pendidik agar dapat terjadi proses perolehan ilmu pengetahuan, penguasaan, kemahiran serta pembentukan sikap dan kepercayaan pada peserta didik. Dengan kata lain pembelajaran adalah proses untuk membantu peserta didik agar dapat belajar dengan baik. Proses pembelajaran dialami sepanjang hayat seseorang manusia serta dapat berlaku di manapun dan kapanpun. Pembelajaran mempunyai pengertian yang mirip dengan pengajaran, walaupun mempunyai konotasi yang berbeda.

Pembelajaran mengandung arti setiap kegiatan yang dirancang untuk membantu seseorang mempelajari suatu kemampuan dan nilai yang baru. Proses pembelajaran pada awalnya meminta guru untuk mengetahui kemampuan dasar yang dimiliki oleh siswa meliputi kemampuan dasarnya, motivasinya, latar belakang pendidikannya, latar belakang ekonominya, dan lain sebagainya. Kesiapan guru untuk mengenal karakteristik siswa dalam pembelajaran merupakan modal utama penyampaian bahan belajar dan menjadi indikator suksesnya pelaksanaan pembelajaran.

Dalam proses pembelajaran guru harus menetapkan terlebih dahulu tujuan pembelajaran yang ingin dicapai.

${ }^{4}$ Tim Pengembang MKDP. Kurikulum dan Pembelajaran (Jakarta : Rajawali Press, 2011), 132. 
Menurut taksonomi Bloom bahwa tujuan pembelajaran adalah sebagai berikut

a. Tujuan pembelajaran ranah kognitif

b. Tujuan pembelajaran ranah afektif

c. Tujuan pembelajaran ranah psikomotorik",

Perbedaan tujuan pembelajaran tersebut akan berimplikasi pula pada adanya perbedaan strategi pembelajaran yang harus diterapkan. Jadi dalam penerapan suatu strategi pembelajaran tidak bisa mengabaikan tujuan pembelajaran yang akan dicapai.

Di samping jenis tujuan pembelajaran tersebut, juga karakteristik peserta didik yang turut memberikan pengaruh sekaligus menjadi perhatian, karena pada diri anak terdapat aspek yang melekat pada dirinya seperti : motivasi, bakat minat, kemampuan awal, gaya belajar, kepribadian dan sebagainya.

Karakteristik peserta didik yang amat kompleks tersebut harus juga dijadikan pijakan dasar dalam menentukan strategi pembelajaran yang akan digunakan. Tampa mempertimbangkan karakteristik peserta didik tersebut, maka penerapan strategi pembelajaran tertentu tidak bisa mencapai hasil belajar secara maksimal. Sebagaimana halnya peserta didik yang memiliki motivasi belajar yang rendah dengan peserta didik yang memiliki motivasi yang tinggi, tentu membutuhkan strategi yang berbeda dalam pembelajaran, demikian pula peserta didik yang memiliki gaya belajar visual dan peserta didik yang memiliki gaya belajar kinestetik, tentu tidak bisa disamakan dalam proses pembelajaran. Oleh karena itu seorang guru hendaknya betul-betul memahami karakteristik peserta didik yang mengikuti proses pembelajaran.

Ada beberapa istilah yang berkaitan dengan pembelajaran yaitu:

1. Teori pembelajaran

Adapun yang dimaksudkan teori adalah "seperangkat prinsip/kaidah/dalil tentang suatu fenomena alam atau sosial

${ }^{5}$ Made Wena. Strategi Pembelajaran Inovatif (Jakarta: PT. BUmi Aksara, 2013), 14. 
yang telah diuji kebenarannya oleh banyak pihak dan dapat digunakan untuk merumuskan serta meramalkan fenomena yang sejenis di tempat dan waktu yang berbeda" ${ }^{\circ}$

2. Pendekatan Pembelajaran.

Adapun yang dimaksudkan dengan pendekatan adalah "titik tolak atau sudut pandang seseorang terhadap suatu obyek atau permasalahan"7

3. Strategi Pembelajaran

Strategi adalah kiat dalam memanfaatkan segala sumber yang dimiliki atau yang dapat dikerahkanuntuk mencapai tujun yang telah ditetapkan, sebagaimana Wina Sengjaya dalam bukunya Mulyono bahwa "strategi pembelajaran adalah suatu kegiatanpembelajaran yang harus dikerjakan guru dan peserta didik agar tujuan pembelajaran dapat dicapai secara efektif dan efisien" Pendekatan pembelajaran yang telah ditetapkan, selanjutnya diaplikasikan dalam strategi pembelajaran.

4. Metode Pembelajaran

Dalam pembelajaran digunakan berbagai metode pembelajaran, jadi metode pembelajaran dapat diartikan sebagai cara yang digunakan untuk mengimplementasikan rencana yang sudah disusun dalam bentuk kegiatan nyata dan praktis untuk mencapai tujuan pembelajaran

5. Tehnik Pembelajaran

Selanjutnya metode pembelajaran dijabarkan ke dalam teknik dan gaya pembelajaran, dengan demikian teknik pembelajaran dapat diartikan sebagai cara yang dilakukan seseorang dalam mengimplementasikan suatu metode secara sfesifik, misalkan penggunaan metode cermah kelas dengan jumlah peserta didik yang relative banyak membutuhkan tehnik tersendiri, yang tentunya secara teknis akan berbeda dengan penggunaan metode ceramah pada kelas yang jumlah peserta didiknya terbatas, demikian pula dengan penggunaan metode diskusi, perlu digunakan teknik yang berbeda pada kelas yang peserta didiknya tergolong aktif dengan kelas yang peserta

${ }^{6}$ Mulyono, MA. Strategi Pembelajaran, Menuju Efektivitas Pembelajaran di Abad Global. (Malang: UIN Maliki Press, 2012), 12.

${ }^{7}$ Ibid., h.13

${ }^{8}$ Ibid. 
didiknya yang tergolong pasif, oleh karena itu guru dapat berganti-ganti teknik meskipun menggunakan metode yang sama

Paling tidak ada empat masalah pokok yang sangat penting dan dapat dijadikan pedoman dalam pelaksanaan pembelajaran., yaitu: 1) Spesifikasi dan kualifikasi perubahan tingkah laku yang diinginkan sebagai hasil pembelajaran, atau apa yang harus dijadikan sasaran dari kegiatan pembelajaran, dan sasaran inilah yang harus dirumuskan secara jelas sehingga mudah dipahami oleh peserta didik, perubahan perilaku dan kepribadian yang diinginkan terjadi setelah peserta didik mengikuti suatu kegiatan pembelajaran; 2) Memilih cara pendekatan pembelajaran yang dianggap paling tepat dan efektif untuk mencapai sasaran. 3) Memilih dan menetapkan prosedur, metode, dan teknik pembelajaran yang dianggap paling tepat dan efektif. Hal ini sangat penting karena suatu metode mungkin hanya cocok dipakai untuk mencapai tujuan tertentu. 4) Menetapkan norma-norma atau criteria keberhasilan sehingga guru mempunyai pegangan yang dapat dijadikan ukuran untuk menilai sampai sejauh mana keberhasilan tugas-tugas dilakukannya.

\section{Komponen Pembelajaran.}

Interaksi merupakan ciri utama kegiatan pembelajaran, baik antara yang belajar dengan lingkungan belajarnya, baik itu guru, teman termasuk sumber belajar dengan lingkungan belajarnya, baik itu guru, teman serta sumber belajar itu sendiri. Di samping itu dalam proses pembelajaran ada beberapa komponen yang harus diketahui oleh seorang guru yaitu antara lain sebagai berikut :
a. Tujuan pembelajaran
b. Materi pembelajaran
c. Metode dan teori pembelajaran
d. Media pembelajaran
e. Penilaian/evalausi pembelajaran ${ }^{9}$

${ }^{9}$ Sudarwan Danim, Menjadi Komunitas Pembelajar, cet, I; (Jakarta: PT. Bumi Aksara, 2004), 421. 
Komponen pembelajaran tersebut sebagai dasar seorang guru dalam melangkah melakukan kegiatan instruksional, sehingga kegiatan pembelajaran dapat dilaksanakan secara sistematis, terarah, maka dengan demikian hasil pembelajaran dapat terukur. Dalam hal ini seorang guru dapat menilai dirinya sendiri, apakah berhasil dalam pembelajaran atau tidak, karena semua indikatornya dapat disaksikan bersama.

Dalam belajar terdapat dua hukum yaitu hukum primer dan hukum sekunder.

1. Hukum primer yaitu :

a. Low of Readines yaitu kesiapan untuk bertindak itu timbul karena penyesuaian diri dengan sekitarnya yang akan memberikan kepuasan

b. Law of Exercise yaitu sesuatu itu akan sangat kuat bila sering dilakukan diklat dan pengulangan

c. Low of Effect yaitu perbuatan yang diikuti dengan dampak / pengaruh yang memuaskan cenderung ingin diulangi lagi dan yang tidak mendatangkan kepuasan cenderung akan dilupakan

2. Hukum sekunder :

a. Low of Multiple Response, yaitu yang dilakukan dengan variasi uji coba dalam menghadapi situasi problematic, maka salah satunya akan berhasil juga.

b. Law of Assimilation, yaitu orang yang mudah menyesuaikan diri dengan situasi baru, asal situasi itu ada unsur yang bersamaan.

c. Low of Partial Activy, yaitu seseorang dapat beraksi secara selektif terhadap kemungkinan yang ada dalam situasi tertentu" 10

Demikian beberapa teori yang sempat dikemukakan dan sekaligus teori tersebut akan menjadi landasan dalam pembahasan hasil penelitian ini.

\section{Blended Learning}

Pembelajaran berbasis blended learning adalah salah satu bagian dari kompetensi peadagogik dan kompetensi profesional,

${ }^{10}$ Ibid., h. 6-7 
sehingga setiap guru mata pelajaran apapun pada dasarnya tanpa kecuali harus menguasai memiliki kemampuan mengaplikasikan media komputer dalam pembelajaran, agar lebih menarik, menyenangkan sehingga hasil belajar lebih bermakna dan tidak membosankan. Di sisi lain, blended learning mengacu pada belajar yang mengkombinasi atau mencampur antara pembelajaran tatap muka (face to face) dan pembelajaran berbasis computer (online dan offline). komposisi blended yang sering digunakan yaitu 50/50 artinya dari alokasi waktu yang disediakan, $50 \%$ untuk kegiatan pembelajaran tatap muka dan $50 \%$ dilakukan pembelajaran online atau $75 / 25$, artinya $75 \%$ pembelajaran tatap muka dan $25 \%$ pembelajaran online, demikian pula $25 / 75$ artinya $25 \%$ pembelajaran tatap muka dan $75 \%$ pembelajaran online" ${ }^{\text {"1 }}$

Dalam praktiknya, Blended learning menggunakan media teknologi cetak, teknologi audio, teknologi audio visual, teknologi computer dan teknologi mobile learning. Belended learning memiliki beberapa kriteria yaitu :

a. E-learning bersifat jaringan yang membuatnya mampu memperbaiki secara cepat, menyimpan atau memunculkan kembali, mendistribusikan pembelajaran dan informasi

b. E-learning dikirimkan kepada pengguna melalui computer dengan menggunakan standar teknologi internet.

c. E-learning terfokus pada pandangan pembelajaran yang paling luas, solusi pembelajaran yang mengungguli paradigm dalam pelatihan.

Dalam Blended learning terdapat beberapa unsur yang harus ada yaitu tatap muka, belajar mandiri, aplikasi, tutorial, kerjasama, evaluasi termasuk dalam menyelsaikan tugas dengan via-email, sehingga akan memudahkan kedua belah pihak antara guru dengan peserta didik.

Kualitas pembelajaran dapat diartikan sebagai suatu kondisi yang menggambarkan tingkat efektivitas suatu pembelajaran.Pembelajaran yang efektif adalah pembelajaran yang menfasilitasi peserta didik aktif berinteraksi dengan

\footnotetext{
${ }^{11}$ Udin Saefudin. Inovasi Pendidikan, (Cet.I; Bandung: Alfabeta, 2008), 5.
} 
berbagai sumber belajar sehingga peserta didik mencapai tujuan pembelajaran secara efektif, efisien dan menyenangkan.

Kualitas pembelajaran dapat dilihat dari dua segi yaitu: segi proses dan segi hasil pembelajaran. Peningkatan kualitas pembelajaran merupakan upaya untuk memperbaiki kualitas proses pembelajaran yang mengarah kepada terjadinya atau munculnya prakarsa belajar oleh peserta didik. Hal ini hanya bisa terjadi jika strategi pembelajaran yang dilakukan berangkat dari landasan teoritikyang cocok, yaitu yang lebih memberi peluang kepada peserta didik untuk mengalami pembelajaran, baik secara mandiri maupun kelompok.

Pembelajaran yang berkualitas juga mencerminkan adanya lingkungan belajar yang memungkinkan peserta didik dapat melakukan control terhadap pemenuhan kebutuhan emosionalnya, melakukan pilihan yang memungkinkannya terlibat secara fisik, emosional, dan mental dalam proses belajar, serta lingkungan yang memberinya kebebasan menentukan pilihan belajar sesuai dengan kemampuan dan kemauannya,pembelajaran yang berkualitas menepatkan peserta didik sebagai subyek dan dapat mengkonstruksi pengetahuan, nilai, dan sikap dengan mudah, penuh gairah dan motivasi serta menyenangkan.

Penggunaan internet sebagai sarana dalam menerapkan blended learning, sebagai salah satu cara untuk meningkatkan dampak positif penggunaan internet, serta mengurangi dampak negatifnya, hal ini tentu saja membutuhkan peran serta para pendidik dalam pengelolaan agar penggunaannya dapat terarah dengan baik serta sesuai dengan tujuan pembelajaran.

Pemanfaatan teknologi dalam pembelajaran bukan hanya sebagai keinginan untuk aksi-aksi, akan tetapi sudah merupakan kebutuhan dan sifatnya sudah sangat mendesak yang diakibatkan oleh derasnya arus informasi dan tuntutan jaman yang semakin maju, sehingga dengan sendirinya akan mengurangi sebagian tugas-tugas guru yang selama ini menjadi beban dalam menyusun persiapan mengajar, akan tetapi bagaimanapun kemajuan suatu teknologi tidak akan mungkin menggantikan posisi guru dalam kelas. Paling tidak teknologi tersebut justru akan memberikan kemudahan dalam menyimpan 
dan menyajikan konsep, dan konsep tersebut lebih terjamin dibandingkan dengan bentuk lembaran kertas yang tentu saja kadang penyimpanan terlupakan sehingga pada saat dibutuhkan butuh waktu yang agak lama untuk mencarinya, sementara dengan cara teknologi penyimpanan lebih aman yang penting jelas identitasnya, agar pada saat dibutuhkan tidak menggunakan waktu yang lama, sebab bagaimanapun yang namanya teknologi tetap memiliki kekurangan dan kelebihan,dan kepada penggunalah ditutut keahlian atau keterampilan untuk memanfaatkannya.

Model pembelajaran saat ini mengikuti perkembangan teknologi informasi melalui teknologi internet, hal inilah yang memunculkan apa yang disebut dengan e-education atau elearning yaitu kegiatan pembelajaran melalui media elektrinik, khususnya melalui jaringan internet. Istilah tersebut lebih dikenal dengan model pembelajaran berbasis computer yang sekarang ini mulai diterapkan hampir seluruh lembaga pendidikan, baik di kota maupun di daerah pedesaan, bahkan dengan perkembangan jaringan internet seakan-akan tidak ada lagi jarak antara kota dengan daerah terpencil.

Di sisi lain, digitalisasi juga mereduksi masalah pembelajaran yang terkait dengan lambatnya pemahaman peserta didik terhadap konsep teori yang bersifat abstrak, artinya bahwa dengan pembelajaran berbasis komputer peserta didik akan lebih mudah memahami konsep-konsep yang bersifat abstrak dan pada akhirnya dapat meningkatkan hasil pembelajaran, mengacu pada masalah tersebut, maka pengembangan pembelajaran berbasis computer sangat penting bagi: guru, peserta didik dan sekolah.

\section{Pembelajaran Berbasis Blended Leaming di Madrasah Tsanawiyah Negeri Model Palu.}

Pemanfaatan teknologi dalam pembelajaran saat ini antara lain adalah pemanfaatan program pembelajaran audio, program pembelajaran video, pemanfaatan TV-Edukasi, pemanfaatan internet, bahkan dengan multimedia pembelajaran merupakan salah satu bentuk alat bantu pembelajaran berbasis computer yang didukung berbagai komponen seperti, teks, 
suara, gambar yang sudah dipelajari oleh peserta didik baik secara kelompok maupun secara mandiri.

Efektivitas pembelajaran seringkali diukur dengan tercapainya tujuan, atau dengan kata lain efektivitas diartikan sebagai ketepatan dalam mengelola suatu situasi. Pengertian ini mengandung ciri yaitu bersistem, karena dilakukan secara teratur, konsisten atau berurutan melalui tahap perencanaan, pengembangan, pelaksanaan, penilaian dan penyempurnaan, sensitive terhadap kebutuhan akan tugas belajar dan kebutuhan pembelajar, kejelasan akan tujuan.

Upaya mewujudkan efektivitas pembelajaran sangat tergantung pada bagaimana guru dpat mengembangkan pembelajaran, efektivitas pembelajaran bukanlah sesuatu yang sederhana atau tentu tidak memadai lagi jika hanya diartikan sebatas transfer ilmu pengerthuan, akan tetapi justru menjadi penting ketika diartikan sebagai pembelajaran yang beroreintasi padapeserta didik

Efektiitas pembelajaran apabila kegiatan pembelajaran dapat mencapai tujuan yaitu peserta didik belajar meraih target sesuai dengan criteria pada perencanaan awal. Pembelajaran dapat dikatakan efektif jika peserta didik dapat menyerap materi pelajaran dan memperaktikannya sehingga memperoleh kompetensi dan keterampilan terbaiknya, atau dengan kata lain guru dapat menggunakan waktu yang sesingkat-singkatnya dengan hasil setingi-tingginya.

Kemampuan guru dalam mengembangkan proses pembelajaran juga turut menentukan efektivitas suatu kegiatan, sehingga guru dituntut untuk lebih berhati-hati dalam menentukan metode pembelajaran, sehingga tidak salah langkah yang kemudian peserta didik menjadi tidak bersemangat. Adapun materi pembelajaran yang kadang menjadi persoalan adalah materi yang sarat dengan praktek, seperti wudhu, atau tayamun, hal tersebut sesungguhnya paling efektif dan efisien adalah dilakukan oleh guru itu sendiri yang kemudian diikuti oleh peserta didik, namun kadang guru ingin menampilkan sesuatu yang lebih menarik, pada hal peserta didik justru tidak simpati, kecuali hal-hal yang materinya agak susah digambarkan dengan kemampuan yang ada pada diri 
seorang guru, misalnya gambar peta, gambar buah-an, gambar binatang, hal ini dapat dipastikan bahwa yang lebih menarik kalau diakses melalui internet, akan tetapi dalam hal-hal yang bisa diperagakan oleh guru atau siswa, untuk sementara masih perlu untuk dipertimbangkan sebagainana sikap peserta didik pada table berikut ini.

Tabel.1

Praktek Wudhu, Shalat Menggunakan Jaringan Internet.

\begin{tabular}{|c|l|c|c|c|}
\hline No. & $\begin{array}{c}\text { Respon } \\
\text { Peserta didik }\end{array}$ & Jumlah & Prosentase & Keterangan \\
\hline 1 & Sangat senang & 9 & 25.71 & \\
\hline 2 & Senang & 21 & 60 & \\
\hline 3 & $\begin{array}{l}\text { Kurang } \\
\text { Senang }\end{array}$ & 5 & 14.29 & \\
\hline 4 & Tidak senang & 0 & 0 & \\
\hline 5 & $\begin{array}{l}\text { Sangat tidak } \\
\text { senang }\end{array}$ & 0 & 0 & \\
\hline & Jumlah total & 35 & 100 & \\
\hline
\end{tabular}

Sumber data :Angket item no..6

Berdasarkan table tersebut, dapat memberikan suatu informasi bahwa praktek wudhu dan shalat, ternyata peserta didik pada umumnya senang dengan menggunakan internet yaitu 21 orang peserta didik atau $60 \%$, yang sangat senang hanya 9 orang atau $25,71 \%$, sedangkan kurang senang dengan alasan tertentu adalah 5 orang atau 14,29\%, hal dapat dipahami bahwa guru dalam proses pembelajaran yang membutuhkan praktek dituntut untuk trampil menggunakan internet, tanpa mengabaikan praktek langsung dari guru itu sendiri yang kemudian diikuti oleh peserta didiknya.

"Bila materi praktek yang diajarkan langsung mengakses lewat internet dan peserta didik mengamati langsung melalui media infokus tentang tata raca yang diperaktekkan ${ }^{, 12}$

\footnotetext{
${ }^{12}$ Mulyadi, S.Pd. Guru”Wawancara" Palu 27 September 2016
} 
Bagaimanapun internet merupakan sarana yang menjadi andalam pada zaman ini, naum tidak semua peserta didik senang atau sangat senang pembelajaran berbasis internet dan pada kenyataannya ada 5 peserta didik justru kurang senang, keadaan seperti ini harus menjadi perhatian seorang guru dan lebih berhati-hati agar peserta didik merasa terlayani dalam proses pembelajaran.

Selanjutnya adalah materi pembelajaran yang dijelaskan oleh guru dengan cara menggabung metode tradisional dengan modern dalam hal ini adalah offline dan online para peserta didik pada umumnya senang. Hasil penelitian ini menunjukkan bahwa pada umumnya peserta didik ingin agar guru dalam menjelaskn materi menggunakan online dan ofline atau penggabungan yaitu sebanyak 16 orang peserta didik atau $45,71 \%$ dengan sikap senang, sedangkan sangat senang sebanyak 11 orang atau $31,43 \%$, sedangakan yang kurang senang hanya sebahagian kecil yaitu 8 orang peserta didik atau $22,86 \%$.

"Penggunaan internet dalam pembelajaran dapat menghemat waktu proses belajar mengajar, menghemat biaya pendidikan secara keseluruhan (peralatan, buku, alat praga) serta lebih mudah pemutakhiran bahan ajar ${ }^{13}$ Penggunaan internet bagi peserta didik memiliki dampak positif yang sangat besar apabila dipergunakan dengan benar, salah satunya adalah dapat meningkatkan hasil belajar, peserta didik dapat dengan mudah mencari informasi mengenai mata pelajaran yang sedang dipelajari, ${ }^{14}$

Selanjutnya bahwa pembelajaran menggunakan online dan offline dianggap efektif dengan alasan bahwa sebelumnya belum menggunakan internet, nilai peserta didik tidak ada yang terlalu menonjol, akan tetapi setelah menggunakan internet nilai peserta didik semaking meningkat, ini disebabkan karena materi pembelajaran bisa diakses kapan dan dimana saja, artinya peserta didik disamping mendengarkan penjelasan guru, juga peserta didik dapat menambah dan mengembangkan materi yang diberiken oleh guru dengan belajar secara mandiri.

"penggunaan teknologi informasi sangat membantu guru dan peserta didik dalam mengembangkan materi ajar, walaupun madrasah

\footnotetext{
${ }^{13}$ Rafli, Guru “wawancara” Palu, 27 september 2016

${ }^{14}$ Rafli, Guru “wawancara” palu 27 September 2016
} 
memiliki buku paket, akan tetapi tidaklah sempurna rasanya jika tidak melibatkan diri atau menyesuaikan dengan perkembangan teknologi, sebab kalau tidak, akan merasa ketinggalan dibandingkan dengan teman-teman yang lainny", 15

Hasil lain dalam penelitian ini menunjukkan bahwa peserta didik senang apabila guru dalam menjelaskan materi diselingi dengan cara online atau offline, karena dengan cara tersebut peserta didik tidak jenuh. Sebagus apapun mata pelajaran, tapi kalau metode yang digunakan guru monoton, maka akan muncul rasa bosan. Pembelajaran online akan memberikan daya tarik tersendiri, karena terdapat variasi yang dapat menghilangkan kejenuhan peserta didik.

Bagi siswa, internet memiliki dampak positif yang sangat besar apabila dipergunakan dengan benar. Salah satunya dapat meningkatkan hasil belajar peserta didik, dapat dengan mudah mencari informasi kapan dan di mana saja mengenai mata pelajaran yang sedang dijalani" ${ }^{\prime \prime 6}$ hal ini sejalan dengan guru yang lain di Madrasah Tsanawiyah Negeri Model Palu yang mengatakan bahwa "Banyaknya materi atau referensi di internet memudahkan peserta didik untuk mencari pembahasan materi yang diajar, ${ }^{, 17}$ di samping itu juga bahwa karena dengan internet peserta didik lebih focus pada obyek tayangan yang diintering di infokus dari internet ${ }^{, 18}$

Kecenderungan peserta didik di Madarsah Tsanawiyah Negeri Model Palu semakin meningkat baik di sekolah maupun di rumahnya masing-masing, keadaan ini akan memberikan semangat sekaligus kemudahan kepada guru-guru, karena materi pembelajaran tidak perlu lagi penjelasan secara detail, karena peserta didik memiliki kecenderungan untuk belajar sendiri, latihan sendiri, bahkan dengan internet disediakan berbagai latihan dengan berbasis game yang mengakibatkan peserta didik tidak hanya belajar tetapi bermain atau dengan kata lain bermain sambil belajar. Di samping itu juga karena di internet gambar tiga dimensi seperti nyata sehingga peserta didik muda menerima pelajaran. Selanjutnya bah wa "dengan menggunakan internet peserta didik akan terfokus untuk

\footnotetext{
${ }^{15}$ Rusno. S.Pd. Guru, "Wawancara” Palu, 28 September 2016

${ }^{16}$ Rafli,Guru. “wawancara” Palu, 27 September 2016

${ }^{17}$ Iqbal, Guru "Wawancara”palu 28 September 2016

${ }^{18}$ Emylia, Guru "Wawancara” Palu, 27 September 2016
} 
belajar, disamping itu juga dapat meningkatkan nilai peserta didik

\section{Efektivitas Blended Learning.}

Berdasarkan hasil observasi awal yang peneliti temukan, menunjukan bahwa pembelajaran di Madrasah Tsanawiyah Negeri Model Palu dilakukan secara tatap muka di ruang kelas dengan dukungan sarana dan prasarana yang memadai, namun pemanfaatan sarana dan prasarana belum optimal, berdasarkan hal tersebut, maka perlu adanya model pembelajaran yang dapat membantu peserta didik dalam mengembangkan kompetensinya, dan salah satu model yang dimaksud adalah blended learning yaitu suatu model yang mengintegrasikan online dan offline dengan mengembangkan teknologi informasi dan komunikasi.

Pembelajaran merupakan suatu proses yang didalamnya mengandung makna bahwa pembelajaran merupakan aktivitas yang berkesinambungan, yang di dalamnya terdapat tahapantahapan aktivitas yang sistematis dan terarah. Pembelajaran merupakan suatu rangkaian aktivitas yang sangat dinamis dan saling berkaitan antara satu dengan yang lainnya, pembelajaran tidak dapat dilepaskan dari interaksi dengan lingkungan, jadi selama proses pembelajaran berlangsung, individu akan senantiasa berada dalam berbagai aktivitas yang tidak terlepas dari lingkungan sekitarnya.

Di samping itu pembelajaran terjadi karena adanya sesuatu tujuan yang ingin dicapai, yakni proses pembelajaran terjadi karena adanya kebutuhan yangharusdipuaskan, serta adanya tujuan yang hendap dicapai. Oleh karena itu pembelajaran terjadi apabila seorang individu merasakan adanya kebutuhan yang mendorong dan ada sesuatu yang perlu dicapai untuk memenuhi kebutuhannya, sehingga pembelajaran merupakan bentuk pengalaman dalam kehidupan yang nyata melalui interaksi seorang individu dengan lingkungannya, sehingga banyak memberikan pengalaman yang nyata, sekaligus merupakan pengalaman dalam kehidupannya. Pembalajaran yang sangat diharapkan di Madrasah Tsanawiyah Negeri Model Palu adalah pembelajaran yang memungkikan 
peserta didik dapat melakukan control terhadap pemenuhan kebutuhan emosionalnya, melakukan pilihan-pilihan yang memungkinkannya terlibat secara fisik, emosional, dan mental dalam proses pembelajaran, serta lingkungan yang memberinya kebeasan menentukan pilihan belajar sesuai dengan kemampuannya dan kemauannya. Hingga saat ini pembelajaran oleh sebahagian guru masih berlangsung sangat konvensional dan berpusat pada guru, dan sebahagian yang lainnya mulai dan melangkah ke pembelajaran yang modern atau dengan istilah pembelajaran yang menggabungkan antara konvensional dan modern atau blended learning, sebagaimana yang menjadi topik dalam pembehasan penelitian ini.

Sesungguhnya banyak faktor yang berpengaruh sekaligus menjadi pendukung terwujudnya proses pembelajaran untuk mencapai tujuan sebagaimana yang diharapkan, salah satu diantaranya adalah penggunaan atau pemanfaatan teknologi dalam proses pembelajaran. Teknologi pembelajaran yang sekarang ini dimiliki oleh Madrasah Tsanawiyah Negeri Model Palu sudah dapat menunjang, dan dapat menyelesaikan masalah-masalah yang muncul dalam proses pembelajaran. Dengan memperhatikan keunggulan teknologi yang dimiliki oleh madrasah tersebut, maka perlu disusun strategi pemanfaatan yang tepat, sehingga efektivitas dan efisiensi pembelajarandapat terlaksana sebagaimana yang diharapkan.Oleh karena itu seorang guru dituntut untuk menguasai berbagai macam metode pembelajaran dan sekaligus penerapannya.dalam pembelajaran agar tidak monoton dalam metode tertentu, akan tetapi perlu metode yang bervariasi. Sehingga setiap peserta didik merasa terpenuhi kebutuhannya, mengingat setiap peserta didik memiliki latar belakang pendidikan yang berbeda antara satu dengan yang lainnya. Adapun respon peserta didik terhadap metode dalam pembelajaran sebagai berikut :

Bagaimanapun seorang guru dituntut menguasai metode pembelajaran sekaligus penerapannya sehingga di dalam proses pembelajaran peserta didik merasa terlayani, walaupun peserta didik sangat bervariasi, baik minat, bakat serta motivasinya termasuk kemampuan memahami penjelasan yang diberikan 
oleh guru juga berbeda-beda, sebab manakalah tidak demikian, maka peserta didik akan merasa bosan, semangat dan motivasi tidak ada, jadi menggunakan metode yang bervariasi dalam proses pembelajaran mutlak adanya, termasuk alat peraga sehingga dalam kondisi apapun alat praga masih sangat dibutuhkan.

"alat peraga dalam pembelajaran bertujuan agar proses pendidikan lebih efektif dengan jalan meningkatkan semangat belajar peserta didik, pembelajaran berlangsung sangat menyenangkan bagi peserta didik apabila seorang guru menggunakan alat praga, karena dengan alat peraga dapat membantu peserta didik untuk lebih cepat mengerti dan memahami materi pelajaran yang diberikan kepadanya ${ }^{, 19}$

Selanjutnya bahwa proses pembelajaran banyak hal yang harus menjadi pertimbangan, walaupun tidak semuanya mengharuskan untuk menggunakannya, artinya salah satu faktor yang menjadi pertimbangan adalah materi pembelajaran, alat pembelajaran serta keadaan peserta didik itu sendiri yang tidak bisa terabaikan dalam menentukan alat pembelajaran yang akan digunakan, .

Dalam proses pembelajaran yang turut menentukan bukan hanya dibutuhkan penerapan metode yang bervariasi, akan tetapi juga faktor alat, seperti infokus adalah penting karena dapat dilihat secara langsung yang dibarengi dengan penjelasan guru.

"senang sekali menggunakan media infokus karena karena proses pembelajaran terjadi lebih efektif dan efisien ${ }^{, 20}$ senada dengan hal tersebut adalah "infokus memiliki kelebihan menampilkan sesuatu yang lebih menarik di samping itu juga guru tidak banyak mencatat dipapan tulis, bahkan dengan infokus bisan menampilkan tayangan audiovisual yang menjadikan pembelajaran semakin menarik ${ }^{, 21}$

Jelaslah bahwa infokus masih sangat dibutuhkan dalam proses pembelajaran, walaupun dalam penggunaannya terdapat tantangan yang tidak ringan, karena penggunaan infokus sangat terkait dengan daya listrik yang mencukupi, ruangan belajar yang memenuhi syarat untuk infokus, termasukkemampuan guru itu sendiri, di samping itu materi juga harus dipersiapkan

\footnotetext{
${ }^{19}$ Rafli, Guru "Wawancara" 28 September 2016

${ }^{20}$ Rusno. S.Pd. Guru "Wawancara" Palu, 26 September 2016

${ }^{21}$ Moh.Asad Dg. Pawata, Guru "Wawancara" Palu 27 september
} 
sedemikian rupa, agar tampilannya lebih menarik dan tidak membosangkan.

\section{Penutup}

Proses pembelajaran di Madrasah Tsanawiyah Negeri Model Palu telah berjalan sebagaimana yang diharapkan, walaupun dari segi strategi, metode, dan media pembelajaran yang digunakan bervariasi sesuai dengan kondisi, baik materi maupun keadaan peserta didik serta kemampuan guru itu sendiri masing-masing berbeda antara satu dengan lainnya. Pembelajaran berbasis blended learning di Madrasah Tsanawiyah Negeri Model Palu, dianggap efektif dan dan efisien karena guru tidak perlu membuat rancangan materinya, cukup mengakses internet dan mencari materi apa yang dibutuhkan termasuk prakteknya dalam bentuk video sehingga akan memudahkan guru, baik dari segi waktu, tenaga dan biaya. Adapun tantangan pembelajaran berbasis blended learning adalah guru dituntut lebih kreatif dan mampu menggunakan jaringan internet, sedangkan peluangnya adalah Madrasah Tsanawiyah Negeri Model Palu sudah dilengkapi sarana atau jaringan untuk melaksanakan pembelajaran blended learning. 


\section{Daftar Pustaka}

Abu Ahmadi. H. Metodologi Penelictian. Cet, IV; Jakarta : PT. Bumi Aksara, 2002

Arikunto Suharsimi, Prosedur Penelitian Suatu Pendekatan Praktek. Cet, XIII; Jakarta : PT Rineka Cipta, 2006

Bobbi Deporter \& Mike Hernacki.Quantum Learning.New York, 1992. Diterjemahkan oleh Alwiyyah Abdurrahman dengan judul :Membiasakan Belajar Nyaman dan Menyenangkan, cet, XXVI; Bandung : PT. Mizan Pustaka, 2008

Brata Suwandi, Ph.d. Metodologi Penelitian, cet, IX; Jakarta : PT. Raja Grafindo, 1995

Direktur Pendidikan Agama Islam.Pedoman Pelaksanaan Peningkatan Kompetensi Guru.Cet. I; Jakarta, 2012

Elain, B. Johnson. Contextual Teaching and Learning. Corwin Press. Inc. Asage Publication Company Thousand Oaks. California. 2002

Hadi Sutrisno. Metodologi Research( Yogyakarta : Jilid 3; Yayasan Penerbitan Fakultas PsikologimUGM, 1973

Hamzah. Prof. Dr. Mengelola Kecerdasan dalam Pembelajaran, cet, I; Jakarta : PT. Bumi Aksara, 2009

Hari Sudrajat. Kurikulum Berbasis Kompetensi. Cet,I; Bandung: CV.Cipta Cekas Cakragrafika, 2004.

Hisyam Zaini. Dkk. Desain Pembelajaran di Perguruan Tinggi. Jogyakarta: IAIN Sunan Kalijaga, 2002

H. Yatim Riyanto, Prof. Dr. Paradigma Baru Pembelajaran, cet, III; Jakarta : Prenada Media Group, 2012

Julia Brannen. Mixing Methods Quantitative and Qualitative Research.Diterjemahkan oleh H. Nuktah Arfawie Kurde dengan Judul.Memadu Metode Penelitian Kualitatif \& Kuantitatif.. Cet. I. Pustaka Pelajar, Yogyakarta, 1997

Keputusan Menteri Agama Nomor 211 Tahun 2011 tentang Pengembangan Standar Nasional Pendidikan Agama Islam

Lie Anita. Cooperative Learning Memperaktekkan Cooperative Learning di Ruang Kelas.Grasindo. 2006 
Made Wena. Strategi Pembelajaran Inovatif Kontemporer Suatu Tinjauan Konseptual Operasional, cet, VIII; Jakarta : PT. Bumi Aksara, 2013

Majid Abdullah. Pendidikan Agama Islam Berbasis Kompetensi.Cet, I; Bandung: PT. Remaja Rosdakarya, 2004

Mohammad Surya. Landasan Menjadi Guru yang Baik. Bogor : Ghalia Indonesia, Jakarta PT. Rineka Cipta, 2007

Mulyono, MA. Strategi Pembelajaran, Menuju Efektivitas Pembelajaran di Abad Global. Malang : UIN Maliki Press, 2012

Nurhadi dkk, Pembelajaran Kontekstual dan Penerapannya dalam KBK. Malang, UNM. 2004

Peraturan Pemerintah RI Nomor 19 tahun 2005 tentang Standar Nasional Pendidikan

Peraturan Pemerintah RI Nomor 74 tahun 2008 tentang Guru Peraturan Pemerintah RI Nomor 16 Tahun 2005 tentang Standar Kualifikasi dan Kompetensi Pendidik

Peraturan Menetri Agama Nomor 16 Tahun 2010 tentang penyelenggaraan Pendidikan Agama pada sekolah

Rosyidi, Imron. Pendidikan Berparadigma Inklusif, Malang : UIN Malang Press, 2009

Sanjaya Wina. Strategi Pembelajaran Berorientasi Standar Pendidikan. Jakarta : Kencana Pranada Media. 2006

Sukardi Ph.D. Prof. Metodologi Penelitian Pendidikan Kompetensi dan Prakteknya. Cet.IV. Jakarta: PT. Bumi A ksara. 2007 Kompetensi Guru dalam Pembelajaran Pendidikan A gama Islam. Jakarta: PT. Bumi A ksara. 2007

Udin Saefudin. Ph.D. Inovasi Pendidikan, Cet.I; Bandung: Alfabeta, 2008

Undang-Undang RI Nomor 20 Tahun 2003 tentangSistem Pendidikan Nasional

Undang-Undang RI Nomor 14 Tahun 2005 tentangGuru dan Dosen 